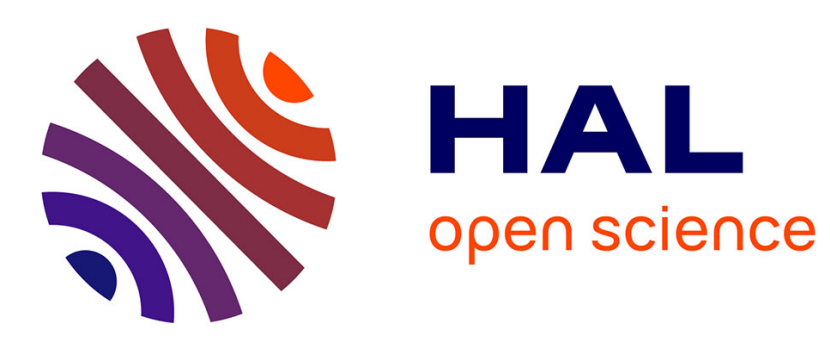

\title{
Conversion and personnel in the Russian military-industrial-complex
}

Ovsey Shkaratan, Jacques Fontanel

\section{To cite this version:}

Ovsey Shkaratan, Jacques Fontanel. Conversion and personnel in the Russian military-industrialcomplex. Defence and Peace Economics, 1998, Conversion of the Russian Defence Industry and Systemic Transformation: An Integrated Approach in Russia, 9 (4), pp.367-379. 10.1080/10430719808404910 . hal-02364240

\section{HAL Id: hal-02364240 \\ https://hal.univ-grenoble-alpes.fr/hal-02364240}

Submitted on 19 Nov 2019

HAL is a multi-disciplinary open access archive for the deposit and dissemination of scientific research documents, whether they are published or not. The documents may come from teaching and research institutions in France or abroad, or from public or private research centers.
L'archive ouverte pluridisciplinaire HAL, est destinée au dépôt et à la diffusion de documents scientifiques de niveau recherche, publiés ou non, émanant des établissements d'enseignement et de recherche français ou étrangers, des laboratoires publics ou privés. 


\title{
Conversion and personnel in the
}

\section{Russian Military-Industrial Complex}

\author{
O. Shkaratan* and J. Fontanel** \\ * Researcher of the Institute for the Economy in Transition \\ ** Professor of Economics, Espace Europe, \\ University Pierre Mendes France of Grenoble \\ Members of the PROMETEE Project, TACIS
}

\section{Introduction}

Militarism is a main feature of the autocratic system, it organises the permanent threat to its existence and it is organically aggressive. Then, the problem of conversion is not based just upon the analysis of the volume and structure of the material resources, it is necessary to take into consideration the people who form Russian's territorial community. The main question is: what are the prospects of entering the labour market for different groups of Russian population? There are two opposed responses. First, Russian workers would not be adapted to market situation, because their labour potential is disappropriated and there is a quick process of disqualification. Second, Russia has created an advanced infrastructure, with an educated people, a good initiative for self-realisations and a decreasing share of waste. In this case, the Russian urban workers correspond to the requirements for the modern world labour market. Then it seems useful to study the social reproduction of human resources with account of their social, professional, regional, ethno-cultural and demographic differentiation and to identify the possible directions of the development of labour potential of Russia.

The best Russian workers and professionals were concentrated in military economy. The main question is : «How to convert the staff of the defence industry ?». It is useful to analyse the importance of the workers of military enterprises and their creative potential. Are they Russia's hope for an up-to-date economy or, just the contrary, are they conservative ballast? The question is not a rhetorical one. Its response is discussed by Russian public as crucial for the economic development of Russia.

\section{The problems of conversion for personnel in the Russian MIC}

The MIC (Military-Industrial Complex) was the core of the Soviet system, absorbing a large quantity of resources, equipment and personnel. Throughout the history of the USSR, the elite was formed by generals and directors of the MIC, who obtained many privileges and a large place in the structure of the Central Committee. The share of military 
expenditure was estimated at 20 to 25 percent of GNP1, and respectively more than 60 percent and 75 percent of all the products of engineering industry and of the whole investment package for science was allotted to military needs. About one third of the national labour force worked directly for the defence interests and about one half of the inhabitants of the country were dependent in some way (members of family, military servicemen, dual branches of industry and agriculture) on the prosperity of the MIC.

The MIC (Military-Industrial Complex) is a basic resource for transforming Russia. The hardest events of the perestroika and post-perestroika periods are tightly connected with the continuing influence and the real power of this part of the Communist elite. Russia has inherited more than 80 percent of the USSR's military-industrial potential (and enterprises), with its extreme organizational, economic and technological monopolisation of activity, the isolation of the MIC from the rest of the economy, its exclusive privileges in financing and supplying (lower prices for components and materials), its inaccessibility to civil sector enterpises, its guarantees of product sales, its preferential right to compete for its personnel (with higher salaries; priority in the distribution of housing; existence of a specialised system of cure and resort institutions; etc.). Enterprises had no right to reorganise their manufacturing and make production smaller in order to maintain the potential of production of military uniforms for possible mobilisation. In the opinion of the Russian ruling circles, the process of conversion includes the military world demand, in order to make the scanty Russian budget free of expenditures on the MIC and replenish the state budget. Moreover, the defence complex presents an increased threat to people's safety, and the possibility of major disasters at military enterprises, only organised on a paranoiac philosophy of the very short run, is extremely important ${ }^{2}$. Finally, the production allocation and transportation of the national economy were constructed on the principle that a war can start tomorrow. Some of the enterprises found ways to produce high-tech products, but the others tried to get military orders and to enter the world weapons market. The aforementionned data on the high share of the MIC in the USSR economy present only limited evidence of its true scale, because in some former Soviet republics which did not enjoy political reliability there were very small military activities. A large proportion of military enterprises has lagged desperatly behind in terms of technology and is still not competitive on the world market, in particular with the emergence of the «Dutch desease» ${ }^{3}$. The workers of these enterprises are used to a parasite attitude and paternalistic guardianship of the state turned out to be in subborn opposition to changes in the country. Meanwhile, the total change of profile of nearly 700 military enterprises to the production of civil products has continued. Dooming enterprises to the production of non-profiled goods means that conversion destroys the innovative potential of the MIC. The defence enterprises and defence research institutes and design offices lost

1Birman, I., Sovetskie voennye raskhody, Oktyabr, 9, 1991, p.153. Birman, I., Ekonomicheskii detektiv, Znanie-Sila, 3, 1991, p.14. 'Vinokur, S., Konversiya i ekonomika: vozmozhen li brak po lyubli ?, Oktyabr, 4, 1992, p.175.

2 Menshikov, S., Economie de la paix en Russie, in Economistes de la Paix, Fontanel ed., Economie en Plus, Presses Universitaires de Grenoble, Grenoble, 1993.

${ }^{3}$ Fontanel, J., I. Borissova and M. Ward, The principles of arms conversion in the case of Russia, Defence and Peace Economics, 6.3, 1995, 237-251. 
approximately 600,000 workers in 1992. The output of the MIC decreased by 65 percent in 1994 and its civil products decreased more significantly than the other civilian enterprises.

For the estimation of human resources, it is useful to differenciate two groups of characteristics. First, indicators reflecting the «vertical line» of societal potential give some comparable and measurable indications, such as the state of population health (including biosocial components of creative productivity) and the components of social potential based on culture, where the indicators of urbanisation and education of population in the context of rooting and intergenerational continuity are very meaningful. Second, the «horizontal line» of societal potential characteristics shows the specific descriptions and structural features preconditioned mainly by the ethnic and cultural peculiarities of population. Cultural traditions (solidarity, integrity, vitality) are not comparable with other nations.

Some statistical studies were developed since 1989, on the orientation, and real working behaviour of Russian workers in usual and high technology enterprises. There were three various surveys:

- First, the workers and the managers (with complete secondary education, at the age of 25-35, in Estonia, Uzbekistan and various regions of Russia) of the sectors of high technology production of the MIC were questioned.

- Second, the survey of governmental level (Gosplan of the USSR and Defence Ministries) was interwieved as experts on the problem of labour and management cultures in the USSR; the selection of respondents, mostly the heads of staff departments, staff training and retraining, labour and salary departments, was based on their supposed knowledge of a few regions'labour and on their social position ; they chose from the list of qualities those which are specific for the labour of definite regions.

- Third, the representative survey of population of Russia has been the core of the research, all categories of adult inhabitants have acted as respondents, in the form of detailed formalised interviews. The mass questioning (3200 respondents) was conducted at January-February 1994 on the Federal network of respondents, organised by the Institute of Sociology of the Russian Academy of Sciences, on the basis of 164 questions concerning various characteristics and qualities of workers (occupation, education, dynamics of professional career, well-off level and life quality, sources and forms of income, organisation of leasure, social origin and social environment, value orientations and motivation of labour behaviour, and so on) and labour market (branch, social and economic type of enterprises, condition of employment, abilities and readiness of respondents to change working place and occupation, etc.).

The MIC workers were shown to be the most troubling and problem group ${ }^{4}$. 65.7 percent of qualified physical labour of industrial type and 100 percent of high-qualified labour of scientific industrial type questioned during the mentioned survey acknowledged this fact. These are the highest rates among the professional groups.

4 We have to note that every responent working at the MIC had put up with a leave with partial payment in the labour market. 


\section{General characteristics of Russian workers}

Three main characteristics were analyzed : health, urbanization and level of education of Russian workers.

Health of Russian population

One of the most essential aspects of human resource quality is the state of physical and mental health of the population. The Soviet regime has demonstrated its achievements, reflected in numbers of medical personnel and hospital beds, in this sphere. It had a leading position in the world by these indices. In 1989, on the eve of the USSR's disintegration there were 47 physicians and 138 beds for 10,000 persons of population. At the same time expenditures for medical services taken as a share in national budget and as an absolute value were expressed by rather modest value, less than 80 rubles to compare with nearly $\$ 1770$ for the USA. Even now the problem of tuberculosis, dysentry, typhoid, measles ou virus hepatitis is not yet settled ${ }^{5}$. The genetic fund is weak for 80 percent of people living in Russia, especially in the Volga and Ural regions ${ }^{6}$. This situation emerged especially within the years of the Soviet regime. Up to 1995, infant mortality became 3 times greater than in the West, at age 1-4 became 7 times greater and at age 30-40, 3.7 times greater ${ }^{7}$. For Sorokin ${ }^{8}$, the policy of the totalitarian machine in the pre-war years was characterised by the most massive and merciless extermination of the genetic fund of the country ${ }^{9}$. The

5 In 1991, the absolute number of people suffering many infectious diseases was 2.5 times greater in Russia than in USA, with a population 1.6 times less, with 5.1 million of mentally diseased people, including 2.6 million of alcoholists and drug addictions (Vishnevskii, A.G. and al, Demograficheskoe polozhenie Rossii, Svobodnaya mysl, 2. 1993, p.75). According to information of medical statistics for 1992 , only 10 percent of the grown-up population of Russian Federation had not any registered chronic diseases (Izvestia, 27 March 1993) and the state of growing generation causes special anxiety, with respectively 14 percent and 20 percent of absolutely healthy schoolboys and schoolgirls in whole and in senior classes (Argumenty i fakti, 1990, $\mathrm{n}^{\circ} 4$. Kharlamov, A., Obrecheny na vyrozhdenie, Kuranty, 23 november 1991).

6 In Orenburg, in the sixties nearly 40 percent of children were born with various defects against nearly 90 percent in 1991 (Kharlamov A., Obrecheny na vyrozhdenie, Kuranty, 23 november 1991.$)$

7 In 1900, if infant mortality was 2 times higher in Russia than in developed countries, mortality at the age 18-70 did not differ significantly and European Russians were 18 times more of hundred aged than in the Western countries. Such a long life was provided by the good state of environment and preserved genetic fund.

${ }^{8}$ Sorokin P.A., Sovremennoe sostoyanie Rossii, in Novyi mir, 1992, n4 ${ }^{\circ}$ pp.184-185 and 188-189.

9 The minimal loss for 1922-1939 was more than 22 million people and 26.6 million more during the Second World War (Andreev, E., Darskii, L. and T. Kharkova, 1990, Otsenka lyudskikh poter' v period Velichoi Otechestvennoi voiny, Vestniik statistiki, $\left.\mathrm{n}^{\circ} 10, \mathrm{p} .27\right)$. In wars and revolutions, the tools of negative selection murdering the best elements of population. 
statistical data of last years showed the significant increase of general mortality rate (from 11.2 in 1990 to 15.7 in $1994^{10}$. So the health level as characteristic of quality of human resources of Russia is not highly appreciated, and the creative ability of the nation is weakened for the future generation, even if there is no direct proofs of the fact.

The level of Russians' urbanization

Data on the level of urbanization is interesting for the analysis of the population's readiness for participation in technological innovations. Means of mass communication create possibilities for accelerated dissemination of the advanced forms of life and for the promotion of a unified systems of values and model of behaviour on a basis of urban culture. After October 1917, the number of city-dwellers increased 6.5 times against increase of the whole population by 1.8 , mainly due to migration in cities 11 . Nonetheless, by 1992,74 percent of Russians lived in cities (75\% for USA, $77 \%$ for Japan and $73 \%$ for Europe as a whole). But metropolitan settlement in Russia is relatively weakly developed, with 13 cities ( 30 for USA) above 1 million inhabitants ( 24 in the former USSR) ${ }^{12}$. High rates of growth of urban population, dramatic collisions connected with forced citydwellers-making of yesterday's peasants, domination of pathological forms of urbanization processes taken together have led to that typical Russian town being inhabited by marginals, who have moved off from traditional culture and could not get the contemporary urban culture. The most part of today's urban inhabitants are the city-dwellers of the first or second generation. The most part of the former highly educated pre-Revolutionary intellectuals had perished and the share of skilled workers was small. The formation of some hybrid anticulture is under way. Towns, streets, clubs, yards and houses began to belong to no one and «let the authorities think about them». New towns, mainly constructed as simple «sleeping cars», close to enormous military enterprises do not possess the infrastructure needed for the reproduction of a cultural citizen. People were spending and continue to spend their free time on standing in queues, working in vegetable gardens, preparing meals, cleaning flats, care for children and watching TV. Only 3 percent of parents spent time on the upbringing of children including walks, talks or musical and language training. The urban intelligentsia turned to be in especially hard position being deprived of the possibility to reproduce and to transfer it to their children. The development of market relations in Russia resulted in the significantly stratified society, where people differ not only of various living standards, but the degree of steadiness the labour market. There is a significant reduction of employment in cities. In 1991, 5.6 million people of able-bodied age were not engaged in national economy and in 1993 the figure

10 For the same period the infant mortality rate increased from 17.4 to 18.6 . The alcoholism and alcohol rate per one hundred thousand was 266.1 in 1985,152 in 1990 and 161.1 in 1994, and the tubercolis rate increased from 34.2 in 1990 to 48.2 in 1994 (Sranitel'nye pokazateli sotsial'no-economitcheskogo polozenia naselenia regionov Rossiiskoi Federatsii, Moscow, Garcomstat Rossiiskoi Federatsii, 1995, pp. 31-34).

11 Shkaratan, O.I., Paradoksy sovetskoi urbanbizatsii, Sud'by sovremennogo goroda, Moscow, 1990, p.16.

12Visnevskii A.G. and al, Demograficheskoe polozhenie Rossii, Svobodnaya mysl, 1993, 2, p. 66. 
increased to 10.1 million people 13 . The process of transformation of this culture into the true urban culture has begun since 1965. A man on the margin of cultures gives place to urbanized individuality. Unity of culture, interests and values of middle strata characterised now the most part of the inhabitants of large cities.

The level of education

There was a relatively good situation of the level of education. Illiteracy was liquidated in the USSR in 1939 and the process of transition to universal and obligatory secondary education was completed up to 1976 . The Soviet successes in space and nuclear weapons were considered to be related to the system of education. Those achievements were preconditioned by exceptional large concentration of resources, time and affords for creation of educated society 14 . In 1990, any 806 of 1000 of Russians older than 15 had higher or secondary education, 3 million students were in the universities and 8.7 million of professionnal with higher education were employed in national economy 15 . Today, that situation in education and science spheres is not so prosperous. In 1950, university expenditures were 1.6 percent of national income and only 0.8 percent in 1985 . The ratio of expenditures for one student to national income per capita in 1950 was 2.3 and 0.4 in 1988, when there were a continuous growth of these indices in Japan and the USA. Such a change of share of expenditures for science and education was partly related with euphoria from success in development of space and military complex, but it was conditioned by the growing structural crisis of the economy. The emigration of the pre-Revolutionary intellectual elite produced a phenomenon, called «obrazovantshina» by Soljenitsin, which means the development of pseudo-educated persons by a deficient training system. Science and technology receive enormous inertia, with a reduction of the connections with foreign universities, ideologisation, corruption and a large uniformisation of education. Successes in 1940 s and 1950s were connected with the creative potential of the national intellectual forces, which had their roots in the high level of scientific culture of the pre-Revolutionary and first post-Revolutionary years. The nine Russian Nobel prize winners were older than 65 and are not alive today. Russian schools traditionally provided a wide range of knowledge in mathematics and natural sciences, exceeding the level of many countries throughout the world, but it was marked by low level of computer hardware and inadequate software. Higher education was extremely bureaucratised and hardly submitted to reforms ${ }^{16}$. Today the situation has not improved and the impoverishment of universities has dramatically increased, apart from some technological universities, connected with defence and located in Moscow and St-Petersbourg. The potential of Russia's educational

13 Osnovnye pokazateli po statistike truda, Moscow, Goscomstat Rossii, 1995; pp.5-6. Sravnitel'nye pokazateli sotsial'no-economitcheskogo polozenia naselenia regionov Rossiiskoi Federatsii, Moscow, Goscomstat Rossiskoi Federatsii, 1995, p.11.

14Drucker, P.F., The educational revolution, in Education, economy and society, 1969, p. 18.

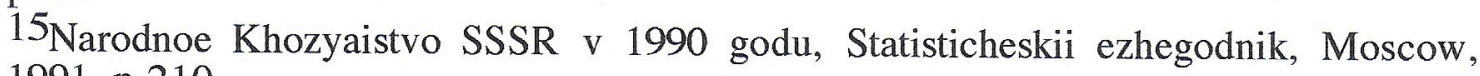
1991, p.210.

16The future information Revolution in the USSR, NY, 1988. p. 38 
system is rather great due to a lot of advanced secondary and higher educational units for preparation of actors of informational economy, but the scale of highly developed education system is not enough for the national requirements.

\section{General characteristics of MIC Russian workers.}

The properties characterising the main Russian workers are the results of the historical beddings of the dramatic destiny of Russian people. One of the main obstacle to the Russian's transition to a market economy is the desire of people to work in the conditions of market and the weak real preparadness to such labour. The habit of paternalism, the equality forms in distribution, the absence of experience of life in conditions of non-guaranteed employment, the unpreparadness for changing of occupation, the residence and the failure to adapt rapidly to changing conditions of activity are very important obstacles for the quality of Russian workers. Value-normative stereotypes in sphere of labour are oriented on stability, invariable conditions, guarantees and state. It is interesting to pick out three main groups : the marginal strata of urban population, the skilled workers of the MIC and the high by skilled workers engagedin sciences, arts or high tech production.

The orientation on getting of new occupation and readiness to more intensive work in conditions of hired labour market reflect the qualities of workers. It is thus impossible to answer unequivocally questions about the Russian readiness to live in conditions of marketisation, because a part of them is not ready to change speciality, to retrain, to pass to more responsible work, etc. The group of qualified physical labour of industrial type in MIC, a group at risk, on threat of unemployment, is not often ready to get a new profession (66.6 percent), The situation is worse with the readiness for responsible work, with only 6.7 percent of them who agree to get more responsibility in their work (36.4 percent among high-skilled workers). The situation of such kind for many million of immobile groups of labour creates serious threats of social conflicts. The MIC enterprises, generally connected with large-scale production with staff number exceeding 1000 persons, are mainly concerned with the reduction of workers, engaged on partial operations, in long technological chains, such as drillers, milling-machine operators and chiselling-machine operators. The high-skilled workers practically do not experience the consequences of mass dismissals, they agree to receive partial payments and they are dismissed only when enterprises were closed. But they can easily find some other work. From the estimations got on the basis of the experts survey, it is clear that first of all the workers of low and average qualifications are sent leave without payment (42.1 percent of low skilled labour in services and 30 percent of skilled labour in services).

MIC workers ( 73.7 percent) are not so concerned by opportunity to lose work and may be they have a reason. Such fear had been state by 26.3 percent. The most alarming for future of Russia is the uncertainty in future, and mass fear to lose work among the people working in technological labour, connected with high technologies (53.8 percent of these people are afraid of losing their work). The tendency exists of transition of people to lower official status by moving to private companies in return of higher earnings. For example, the shares of watchmen and guards (1.3 percent in 1995 and 0.4 percent in 1985), of cleaners and other representatives of junior attendants (1.8 percent in 1995 and 1.1 percent in 
1985), of cashiers, controllers, acountants (2.1 in 1995 and 1.5 in 1985) expressed the tendency to have a better-payed job, with lower qualification, in private enterprises. Meantime, the decrease of teachers of higher educational institutes is important $(1.2$ percent in 1985 and 0.5 percent in 1995).

Experts from the Federal Employment Service and personal services see Russia's future to be a new addition to the world economy. The directors of the MIC, questioned as experts, showed more confidence in Russia's future, because the production of MIC entreprises is competitive at the world market. Their opinion was supported by the high qualified labour available, its relatively low cost and Russian's natural resources.The MIC directors, with their over-estimation of the industry's role in current conditions, their conservatism and their lack of wish to catch up the development of the world development, expects the major demand for the qualified labour of industrial type and the experts for the qualified labour of finance and management. Answering the question about the most prospective fields of activity in the nearest future, demanding supplementary labour, more than 30 percent of experts named the fields of high tech and informational technologies, the MIC enterprises which are mainly export oriented. The expert survey data evaluate the main characteristic features of MIC Russian workers (Table 1).

Table 1. The main qualities of the MIC Russian workers

Degree of Quality

Characteristics

Good quality

- ability to intense labour,

- striving for collective work,

- feeling of participation in common activity

- professional universality,

- inclination for original, innovative a rationalising decisions,

- readiness to help without payment,

- quick reaction on changing circumstances,

- inclination to risk,

- readiness to obey to informal leader

- preference of free individual rhythm of wo

- prestige of industrial,

- bad attitude to rapid career makers.

- Punctuality,

- self-discipline,

- responsability for results of their work,

- striving for a professional career or 1

prestige of hierarchical growth,

- achievement of high level of professior skill, 
- will for originality,

- ability to act according to circumstances, complicated hand work, to concentri attention and energy for a long time, to $s \epsilon$ control, to keep balance and control emotic in hard situations, the adherence to tradition well-known, habitual, the loyalty towa1 administration, the inclination to rely upon 1 heads and to subordination, the feeling proud for the organisation and devotion to it

- They consider that some characteristics are not very good, such as

- The experts estimated that the MIC Russian workers have no ability for a monotonous stereotyped labour, for a preference of fixed rhythm technologies, for an adherence to individual forms of labour and for a high level of personal claims and ambitions.

There are three main segments of the labour market of Russia, approximately equal in number, the white-collar workers (mainly having education on a college or university level), the skilled workers (mainly in construction, engineering, transport sectors, with a level of secondary school) and the low-skilled and non-skilled workers (mainly in service sphere and auxiliary works in industrial sectors). From the point of view of creation of an information economy and innovative development in Russia, quantity and quality of human resources may be evaluated as sufficient. The trend of world economy to personification of consumer properties of goods when usual goods get features of intellectual ones is promising for Russian workers. This transition from the model of mass production to diversification of products to satisfy the specialised demand is interesting for the Russian labour market.

\section{Conclusions}

Russian workers are adequate to the requirements of a labour force for the information economy, with the necessity of permanent mastering of new professional knowledge and skills, need of profile and professional functions due to mastering of adjacent occupations, collective responsability of personnel for observation of technological process and preservation of equipment. In some key sectors of up-to-date economy, which predetermine the competitiveness of a nation at the world market (microelectonics, telecommunications, biotechnology), Russia has lagged behind considerably. It is still keeping strong positions in aerospace and nuclear branches. Therefore, the potential of Russia's human resources cannot be realised without active co-operation on a mutually profitable basis with firms and corporations of other countries. 
Andreev, E., Darskii L. and Khar'kova T., Otsenka lyudskikh poter' v period Velichoi Otechestvennoi voiny, in Vestniik statistiki, 1990, n 10.

Birman, I., Sovetskie voennye raskhody, Oktyabr, 9, 1991.

Birman, I., Ekonomicheskii detektiv, Znanie-Sila, 3, 1991.

Drucker, P.F., The educational revolution, in Education, economy and society, 1969.
Fontanel, J., Economistes de la paix, Economie en Plus, Presses Universitaires de
renoble, Grenoble, 1993. Grenoble, Grenoble, 1993.

Fontanel, J., I. Borissova and M. Ward, The principles of arms conversion in the case of Russia, Defence and Peace Economics, 6.3, 1995.

Goscomstat Rossii, Osnovnye pokazateli po statistike truda, Moscow, Goscomstat

Goscomstat Rossiiskoi Federatsii, Sranitel'nye pokazateli sotsial'no-economitcheskogo polozenia naselenia regionov Rossiiskoi Federatsii, Moscow, Goscomstat Rossiiskoi

Izvestia, 27 March 1993.

Kharlamov, A., Obrecheny na vyrozhdenie, Kuranty, 23 november 1991.

Kharlamov A., Obrecheny na vyrozhdenie, Kuranty, 23 november 1991.

Lebedev O. , Itog Oktyabrya, in Znanie-sila, 1992, n5-7.

Economie en Plus, Presses Unival pas

Shkaratan, O.I., Paradoks sovetsk de Grenoble, Grenoble, 1993. Moscow, 1990.

Sorokin P.A., Sovremennoe sostoyanie Rossii, in Novyi mir, 1992, n 4 .
Statisticheskii ezhegodnik, Narodnoe Khozyaistvo SSSR v 1990 godu, Statisticheskii
hegodnik, Moscow, 1991. zhegodnik, Moscow, 1991.

Vinokur, S., Konversiya i ekonomika : vozmozhen li brak po lyubli ?, Oktyabr, 4, 1992. 1993

Vishnevskii, A.G. and al, Demograficheskoe polozhenie Rossii, Svobodnaya mysl, 2. 